\title{
The Influence of Nickel and Tin Additives on the Microstructural and Mechanical Properties of Al-Zn-Mg-Cu Alloys
}

\author{
Haider T. Naeem, ${ }^{1,2}$ Kahtan S. Mohammed, ${ }^{1}$ Khairel R. Ahmad, ${ }^{1}$ and Azmi Rahmat ${ }^{1}$ \\ ${ }^{1}$ School of Materials Engineering, University Malaysia Perils, Taman Muhibbah, 02600 Jejawi, Perlis, Malaysia \\ ${ }^{2}$ College of Engineering, Al-Muthana University, Al-Muthana, Iraq \\ Correspondence should be addressed to Haider T. Naeem; haider_neem@yahoo.com
}

Received 16 October 2013; Accepted 3 January 2014; Published 19 February 2014

Academic Editor: Pavel Lejcek

Copyright (C) 2014 Haider T. Naeem et al. This is an open access article distributed under the Creative Commons Attribution License, which permits unrestricted use, distribution, and reproduction in any medium, provided the original work is properly cited.

\begin{abstract}
The effects of nickel and nickel combined tin additions on mechanical properties and microstructural evolutions of aluminumzinc-magnesium-copper alloys were investigated. Aluminum alloys containing $\mathrm{Ni}$ and $\mathrm{Sn}$ additives were homogenized at different temperatures conditions and then aged at $120^{\circ} \mathrm{C}$ for $24 \mathrm{~h}(\mathrm{~T} 6)$ and retrogressed at $180^{\circ} \mathrm{C}$ for $30 \mathrm{~min}$ and then reaged at $120^{\circ} \mathrm{C}$ for $24 \mathrm{~h}$ (RRA). Comparison of the ultimate tensile strength (UTS) of as-quenched Al-Zn-Mg-Cu-Ni and Al-Zn-Mg-Cu-Ni-Sn alloys with that of similar alloys which underwent aging treatment at T6 temper showed that gains in tensile strengths by $385 \mathrm{MPa}$ and $370 \mathrm{MPa}$ were attained, respectively. These improvements are attributed to the precipitation hardening effects of the alloying element within the base alloy and the formation of nickel/tin-rich dispersoid compounds. These intermetallic compounds retard the grain growth, lead to grain refinement, and result in further strengthening effects. The outcomes of the retrogression and reaging processes which were carried on aluminum alloys indicate that the mechanical strength and Vickers hardness have been enhanced much better than under the aging at $\mathrm{T} 6$ temper.
\end{abstract}

\section{Introduction}

With the growing demands of the airline industries, various efforts were taken to develop modern advanced structural materials. Super high-strength aluminum alloys ( $\mathrm{Al}-\mathrm{Zn}-\mathrm{Mg}$ $\mathrm{Cu}$ ) have attracted much attention in the aerospace fields due to their excellent combination of low density and highstrength $[1,2]$. Recently, attempts, including a chemical composition modification for an $\mathrm{Al}-\mathrm{Zn}-\mathrm{Mg}-\mathrm{Cu}$ alloy and employing new heat treatments, were made to further increase the properties of these alloys. Zhao and Tsuchida [3] found that adding chromium $(\mathrm{Cr})$ or zirconium $(\mathrm{Zr})$ into AA 7075 aluminum alloy could inhibit the grain coarsening. Chaubey et al. [4] observed that an addition of cerium (Ce) into Al$\mathrm{Zn}-\mathrm{Mg}-\mathrm{Cu}$ alloy has resulted in up to $5 \%$ grain refinement of the cast dendritic structure as well as up to $38 \%$ refinement of heat-treated microstructure. However, the applications of the rare-earth metals contained in aluminum alloys are extremely restricted due to their high cost. Therefore, more attention has been paid to the transition metals which are cheap such as nickel. Previous research showed that nickel plays an important role in solid solution strengthening and can effectively improve the mechanical properties of Al-7Si alloys [5]. Farkoosh et al. [6] assessed the phase formation in an Al$\mathrm{Si}-\mathrm{Cu}-\mathrm{Mg}$-Ni alloy through adding nickel (0-1 wt.\%); also, the $\mathrm{Al}_{3} \mathrm{CuNi}$ phase has greater influence on the overall strength of the alloy compared to other Ni-bearing precipitates. At present, studies on $\mathrm{Al}-\mathrm{Zn}-\mathrm{Mg}$-Cu alloys are developed which modified most of them by nickel with various techniques like a rapid solidification (RS) $[7,8]$. While the researchers on the impacts of nickel and tin additives which added to an $\mathrm{Al}-\mathrm{Zn}-\mathrm{Mg}-\mathrm{Cu}$ alloy by the another casting process, especially they were a joint effect, is very few. In the present work, the influences of $\mathrm{Ni}$ and $\mathrm{Sn}$ on the microstructure and mechanical properties of $\mathrm{Al}-\mathrm{Zn}-\mathrm{Mg}$-Cu alloys produced by a semichilling casting process were investigated. In order to optimize the 
TABLE 1: The chemical composition of the alloys.

\begin{tabular}{|c|c|c|c|c|c|c|c|c|c|c|c|}
\hline \multirow{2}{*}{ Alloy } & \multicolumn{11}{|c|}{ Chemical composition (wt. \%) } \\
\hline & $\mathrm{Si}$ & $\mathrm{Fe}$ & $\mathrm{Cu}$ & $\mathrm{Mn}$ & $\mathrm{Mg}$ & $\mathrm{Cr}$ & $\mathrm{Ni}$ & $\mathrm{Zn}$ & $\mathrm{Ti}$ & $\mathrm{Sn}$ & $\mathrm{Al}$ \\
\hline Base alloy & 0.078 & 0.234 & 1.774 & 0.044 & 2.886 & 0.187 & - & 6.676 & 0.027 & - & Bal. \\
\hline Alloy A & 0.092 & 0.220 & 1.606 & 0.044 & 2.756 & 0.185 & 0.557 & 6.683 & 0.043 & - & Bal. \\
\hline Alloy B & 0.130 & 0.389 & 1.641 & 0.46 & 2.817 & 0.181 & 0.57 & 7.615 & 0.048 & 0.511 & Bal. \\
\hline
\end{tabular}

TABLE 2: The heat treatment steps of studied alloys after the extrusion process.

\begin{tabular}{|c|c|c|}
\hline Number of treatment & Type & Details of treatment \\
\hline 1 & Homogenizing & $450^{\circ} \mathrm{C}$ for $2 \mathrm{~h}+470^{\circ} \mathrm{C}$ for $24 \mathrm{~h}+480^{\circ} \mathrm{C}$ for $0.5 \mathrm{~h}$ \\
\hline 2 & Peak ageing (T6) & $120^{\circ} \mathrm{C}$ for $24 \mathrm{~h}$ (peak ageing) \\
\hline 3 & Retrogression and reaging (RRA) & $\begin{array}{l}120^{\circ} \mathrm{C} \text { for } 24 \mathrm{~h} \text { (peak ageing) }+180^{\circ} \mathrm{C} \text { for } 0.5 \mathrm{~h} \\
(\text { retrogression })+120^{\circ} \mathrm{C} \text { for } 24 \mathrm{~h} \text { (reageing) }\end{array}$ \\
\hline
\end{tabular}

role of $\mathrm{Ni}$ and $\mathrm{Sn}$ additives on $\mathrm{Al}-\mathrm{Zn}-\mathrm{Mg}-\mathrm{Cu}$ alloys, the retrogression and reaging were carried out on these alloys.

\section{Experimental Procedures}

2.1. Research Material. The present study was carried out on $\mathrm{Al}-\mathrm{Zn}-\mathrm{Mg}-\mathrm{Cu}$ aluminium alloy ingots provided by ALCAN GLOBAL AEROSPACE. The ingots were $13 \mathrm{~mm}$ thick and $20 \mathrm{~mm}$ wide. Nickel and tin granular additives of $99 \%$ and 99.5\% purity, respectively, were provided by Merck KGaA. The nominal compositions of the studied alloys are listed in Table 1. The terms "Base alloy," "Alloy A," and "Alloy B" refer to the as-received alloy, alloy with $0.5 \mathrm{wt} . \% \mathrm{Ni}$, and alloy with a combined $0.5 \mathrm{wt}$.\% Ni plus $0.5 \mathrm{wt} . \% \mathrm{Sn}$ additions, respectively. The chemical composition analysis was carried out using the arc-spark spectrometer.

The alloys were remelted in a graphite crucible at $1123 \mathrm{~K}$ in an electrical resistance furnace (with accuracy of $\pm 5^{\circ} \mathrm{C}$ ). The samples were produced by a semidirect chilling (DC) casting process conducted in a cylindrical iron steel mold of dia.in-out $35-45 \mathrm{~mm}^{2} \times$ height $150 \mathrm{~mm}$. The mold was preheated to $523 \mathrm{~K}$ prior to the casting process. The cooling rate of $-7 \mathrm{~K} / \mathrm{s}$ and water flow rate were about 45 liters per minute. The alloys were inverted and remelted three times to ensure complete mixing. After the casting, homogenizing treatments conducted for alloys according to $[9,10]$, within the step number 1 in Table 2, were followed by quenching in cool water immediately after each step of the homogenizing treatments. After quenching, an extrusion process was performed on the cast bars. In order to accomplish so, the alloy bars and extrusion mold were preheated to $400^{\circ} \mathrm{C}$ and to $450^{\circ} \mathrm{C}$ for 30 minutes in electrical resistance furnaces. After extrusion, the samples were quenched in cool water. The extrusion rate was about 3.5. During the extrusion process, wax was used as a lubricant material. The extruded bars were undergoing separately at $450^{\circ} \mathrm{C}$ and $470^{\circ} \mathrm{C}$ for $1 \mathrm{~h}$ and then kept at $480^{\circ} \mathrm{C}$ for $30 \mathrm{~min}$ for further homogenizing treatment. Finally, they were quenched in cold water immediately after each step. In this study, all the extruded samples were tempered according to the procedure in Table 2. After each step of the heat treatment T6 temper and RRA process, the specimens were quenched in cool water.

2.2. Microstructure Characterizations. The microstructures were analyzed by the optical microscopy (OM) using Olympus PMG3 optical microscope. The specimens were extracted from a position of $1 / 2$ height of the ingot, ground, and polished according to ASTM E3-01. They were etched with Keller's reagent. The average grains' size analysis was carried out using the linear intercept method. To characterize the effect of additives on the microstructural, the scanning electron microscopy (SEM-JEOL JSM-6460LA analytical scanning electron microscope) along with an energy dispersive spectroscopy (EDS) was used. The X-ray diffraction analysis (XRD-Lab X, XRD-6000, SHIMADZU, under the operating conditions: scan range: $20^{\circ}-80^{\circ}$, step size: 0.03 , and scan rate: $5^{\circ} / \mathrm{min}$ ) has been used to identify the intermetallic compounds of alloys. The calculation of the average grain size and its analysis were carried out using the linear intercept method.

2.3. Mechanical Testing. The $\mathrm{Hv}$ microhardness measurements were carried out on the specimens according to ASTM E92-82, "Mitutoyo DX256 series." Indentation force was set to $30 \mathrm{~N}$ and $10 \mathrm{sec}$ dwell time. To ensure cleanliness the surfaces of the samples were polished prior to Hv measurement. Each reading was an average of at least ten separate measurements taken randomly on the surface of the specimens.

The tensile test was carried out at an ambient temperature on a round tensile specimen with dimension of length $90 \mathrm{~mm} \times$ dia. $65 \mathrm{~mm}^{2}$ using an INSTRON testing machine with a ram speed of $10 \mathrm{~mm} /$ minute and a load of $500 \mathrm{kN}$. Three rods were tested to ensure the right results. The tensile test specimens were prepared according to ASTM B557M$02 \mathrm{a}$.

\section{Results}

Figures 1(a) and 1(b) show the optical micrographs of the as-quenched alloy A and alloy B samples. The structure of samples casting consists of the equi-axed grains are clear 


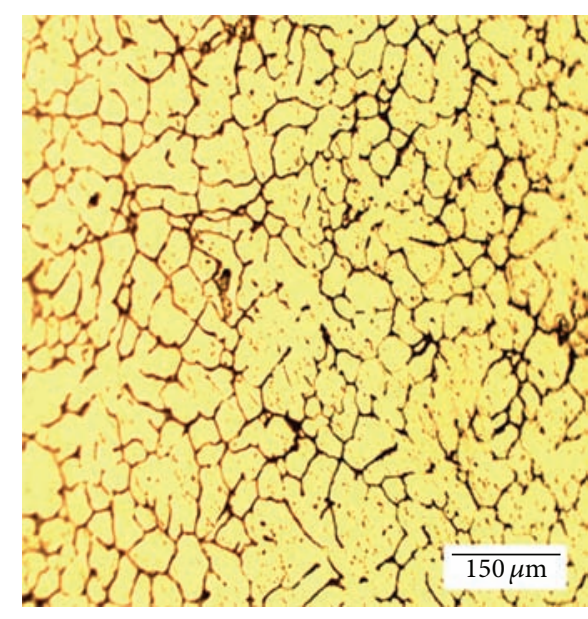

(a)

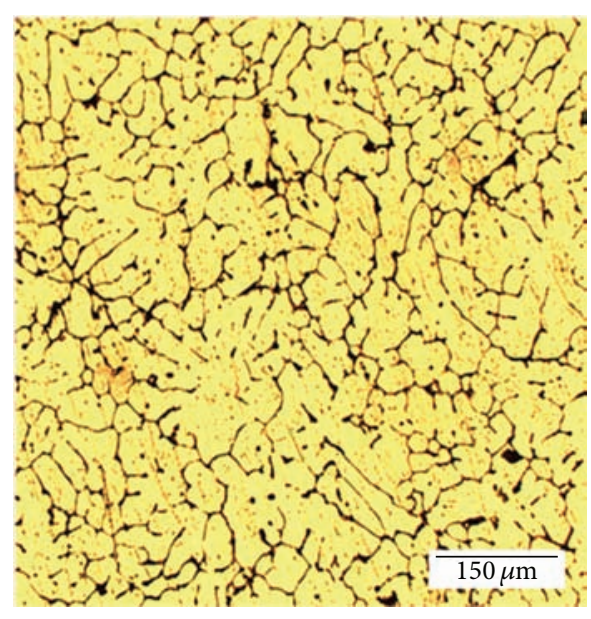

(b)

Figure 1: Optical microstructures of as-quenched (a) alloy A and (b) alloy B samples.

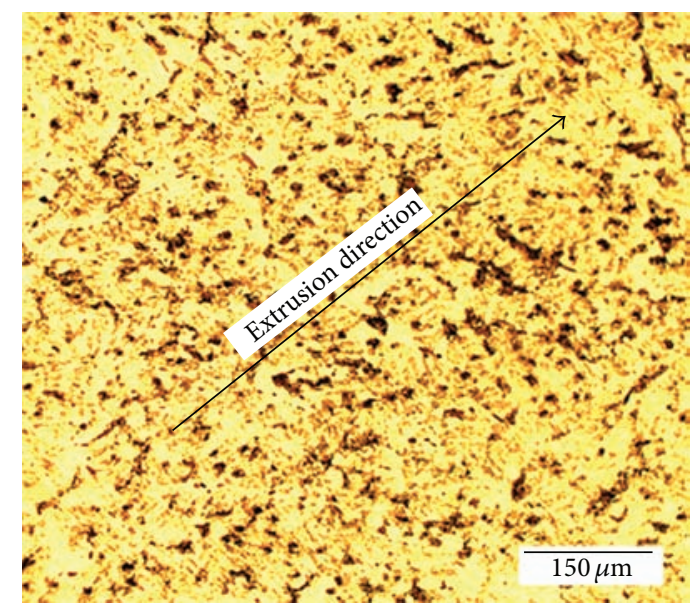

(a)

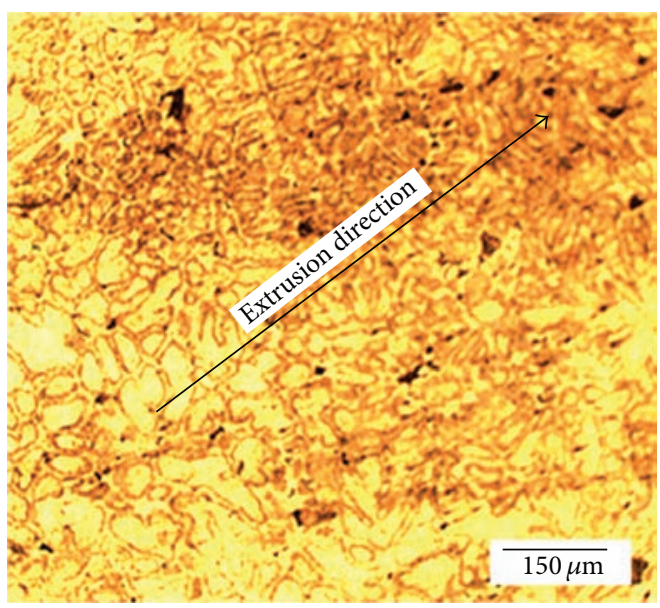

(b)

Figure 2: Optical microstructures of (a) alloy A and (b) alloy B after T6 temper.

within aluminum-rich solid solution this equiaxed due to the effectiveness of the semi-chill casting mechanism an addition to impact of the nickel additives cause of the interdendritic network of the intermetallic compounds. In general, grain refining is normally employed during chill casting mechanism; the structure refined by increasing the heat extraction occurs from the surface and corresponding increase at the solidification rate [11]. The grain size is reduced for the alloys A, B in Figures 1(a) and 1(b) with adding nickel to the base alloy. Generally, the idea behind a decrease in the grain size is attributed to the grain refinement mechanism which is the increase as the number of solidification sites for heterogeneous nucleation of the primary aluminum phase $[12,13]$. Particles of a nickel act as substrates within the matrix base alloy. The grain refiner effectiveness is judged through the grain size and morphology, where if the grain morphology was equiaxed, this leads to a finer structure which in turn allows for advantages of grain refinement such as improved mechanical properties [14].
Further the average grain size of the as-quenched alloy A and alloy B samples is about 39 and $43 \mu \mathrm{m}$, respectively; compare with the as quenched base alloy in our prior study where the average grain size of was $47 \mu \mathrm{m}$ [15]. Previous studies indicate an average grain size; Deng et al. [16] reported a grain size of about $121 \mu \mathrm{m}$ for as-cast AA 7050 aluminum alloy. He et al. [17] gave the grain size about $250 \mu \mathrm{m}$ for as-cast $\mathrm{Al}-\mathrm{Zn}-\mathrm{Mg}-\mathrm{Cu}$ alloy. Semi-direct chill casting findings in this study confirmed the efficiency of the technique in the grain refinement and enhancement of mechanical properties.

Figures 2(a) and 2(b) show the optical micrographs of the alloy samples after promoting homogenizing and hot extrusion and then the aging treatment at T6 temper. The average grain size was about 31 and $36 \mu \mathrm{m}$ for alloy A and alloy B samples, respectively.

Figures 3(a) and 3(b) show the optical micrographs of the alloy A and alloy B specimens after the RRA process. The average grain size of these alloys was about 33 and 


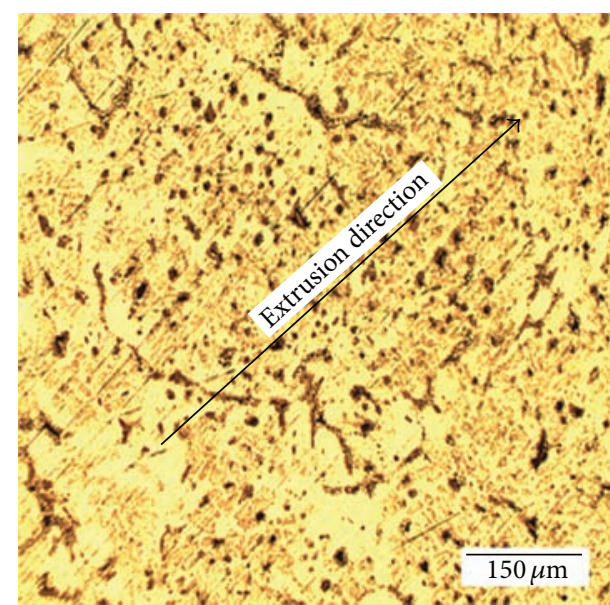

(a)

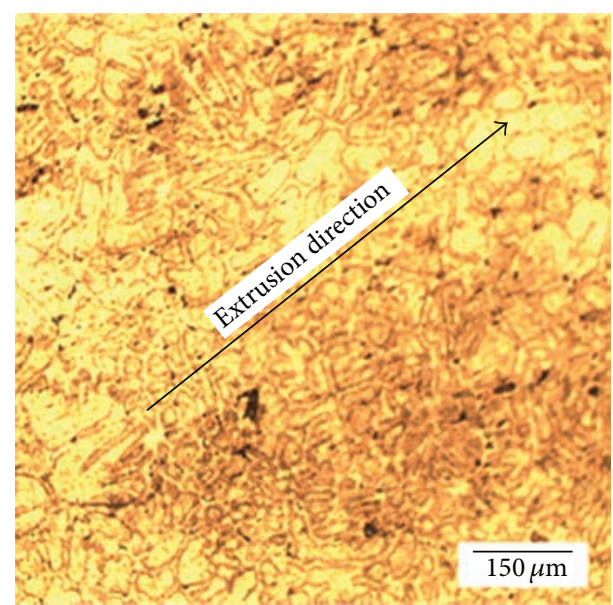

(b)

FIgURE 3: Optical micrographs of (a) alloy A and (b) alloy B after the RRA process.

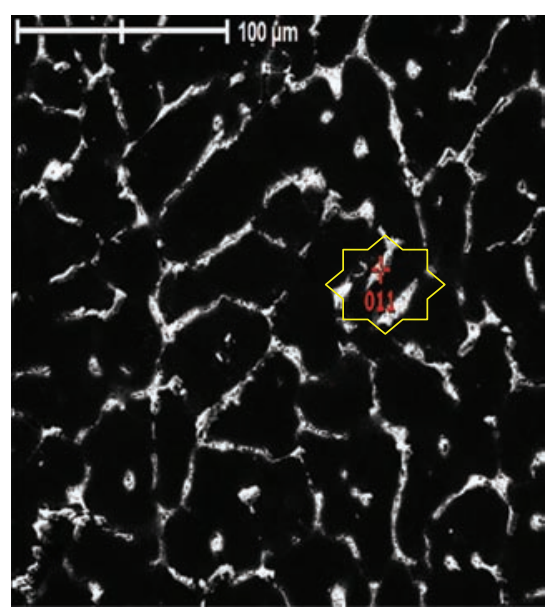

(a)

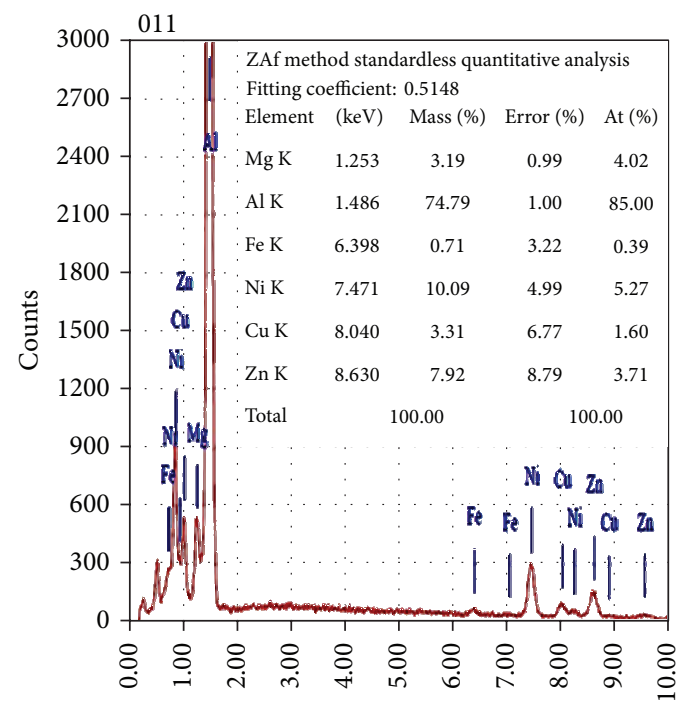

(keV)

FIGURE 4: The (a) SEM and (b) EDS microanalysis of as-quenched alloy A sample.

$39 \mu \mathrm{m}$, respectively. The grain size of alloy A samples in Figures 2(a) and 3(a) was significantly reduced after applying the T6 and RRA processes due to the increase to extensive hot extruding process. Furthermore, with adding nickel into aluminum alloys wherein the eutectic reaction led to creating dispersion compounds within the matrix of the alloys, the interaction of the base alloy matrix underwent heat treatment (T6, RRA) with the nickel-rich disperse particles. The newly formed compound of the dispersed particles restricts the recrystallization and grain growth in subsequent stages.

The scanning electron micrograph (SEM) in Figure 4(a) depicts the microstructure of the as-quenched alloy "A" sample. The dark areas indicate the primary solid solution, and the bright areas indicate the nonequilibrium eutectic solid solution between the grains. Gray particles in the labeled region are prevalent; the energy-dispersive spectroscopy (EDS) scanned analysis in Figure 4(b) suggests that the stoichiometry is similar to $\mathrm{T}-(\mathrm{Al} \mathrm{Mg} \mathrm{Zn})$ and $\mathrm{S}-(\mathrm{Al} \mathrm{Cu} \mathrm{Mg})$ phase with $\gamma$-(Al-Cu-Ni-Fe) phases.

The SEM micrograph of the alloy "A" sample after T6 temper in Figure 5(a). It shows the prevalence of Ni-rich dispersoids particles within the matrix. Figure 5(b) reveals the chemical composition close to $\mathrm{T}-(\mathrm{Al} \mathrm{Mg} \mathrm{Zn})$ and $\mathrm{S}-(\mathrm{Al}$ $\mathrm{Cu} \mathrm{Mg}$ ) phase with $\gamma$-(Al-Cu-Ni-Fe) phases.

SEM image in Figure 6 shows the microstructure of the alloy "A" sample undergoing RRA process. The bright areas denote the newly formed phases in addition to the dispersoids particles. Figure 6(a) shows the numerous dispersed particles. Figure 6(b) reveals a similar stoichiometry to that of T$(\mathrm{Al} \mathrm{Mg} \mathrm{Zn)} \mathrm{and} \mathrm{S-(Al} \mathrm{Cu} \mathrm{Mg)} \mathrm{phase} \mathrm{with} \gamma$-(Al-Cu-Ni-Fe) 


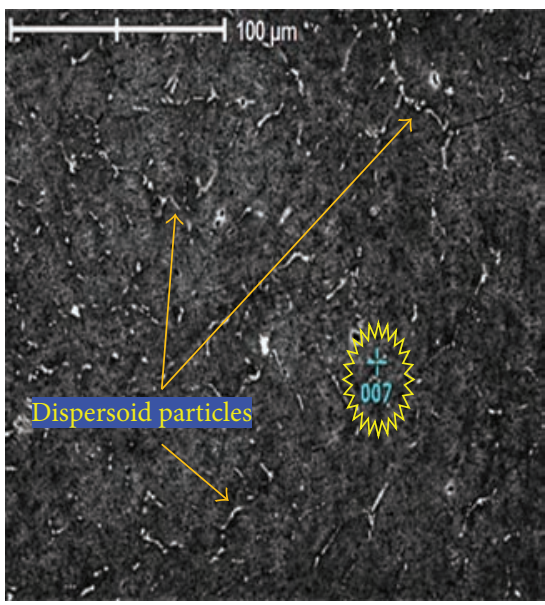

(a)

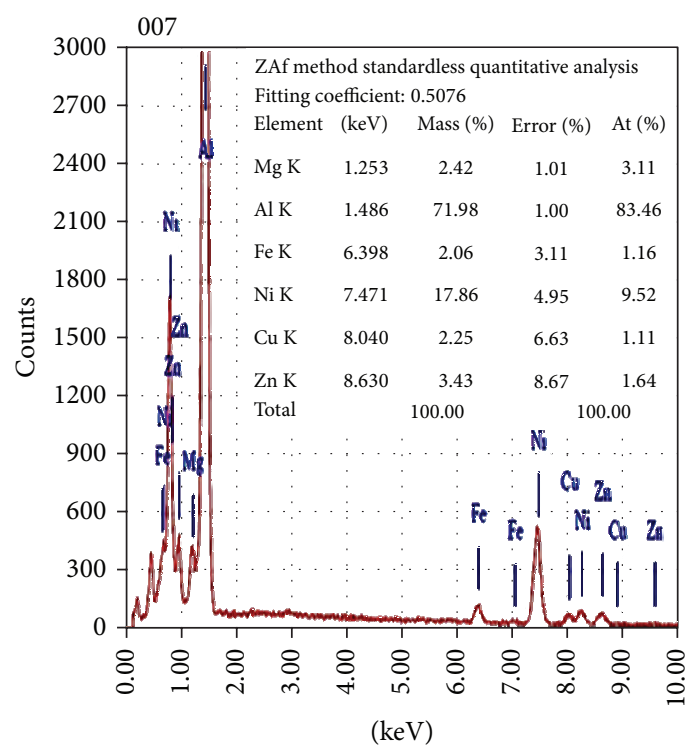

(b)

FIGURE 5: The (a) SEM and (b) EDS microanalysis of alloy "A" sample after T6 temper process.

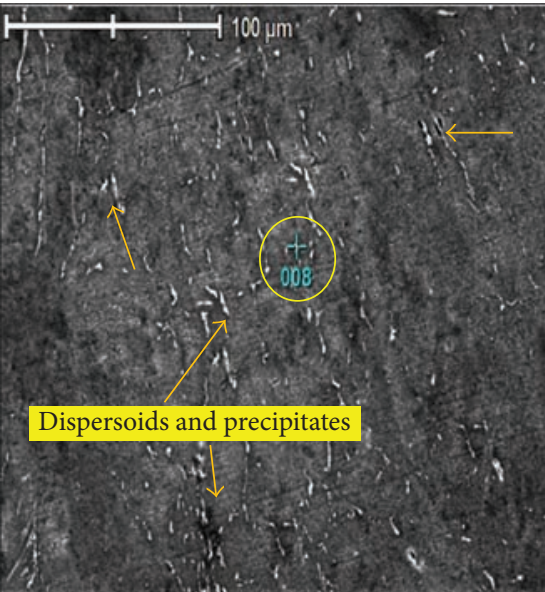

(a)

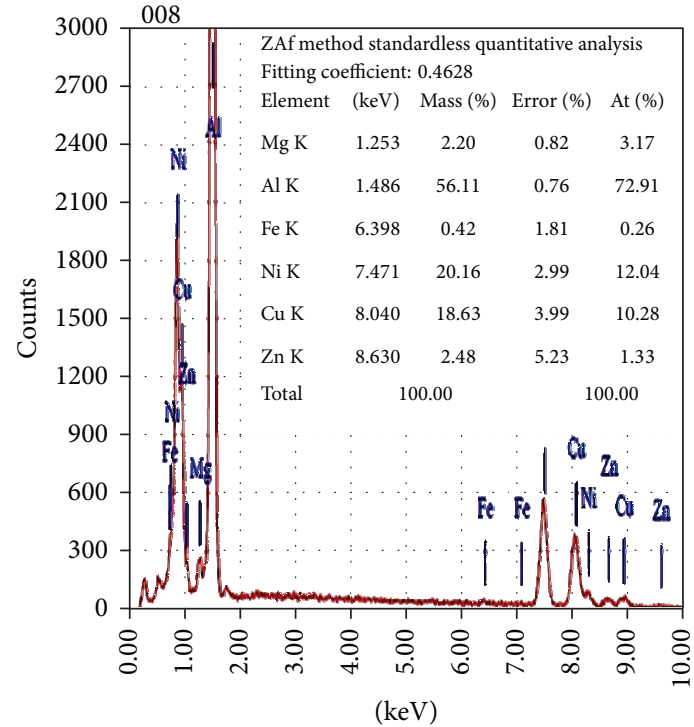

(b)

FIgURE 6: The (a) SEM and (b) EDS analysis of alloy "A" sample after the RRA process.

phases. During the RRA process further the secondary phase particles are precipitated into the matrix.

Figure 7 shows comparison of the X-ray diffraction (XRD) patterns of alloy A after quenching, T6 temper, and RRA process. The as-quenched alloy "A" XRD pattern in Figure $7(\mathrm{c})$ was primarily composed of the alpha aluminum, the secondary phases, and intermetallic compounds ( $\mathrm{T}$ $\mathrm{Al}_{5} \mathrm{Mg}_{11} \mathrm{Zn}_{4}, \mathrm{~S}-\mathrm{Al}_{2} \mathrm{CuMg}, \mathrm{Al}_{7} \mathrm{Cu}_{4} \mathrm{Ni}, \mathrm{Al}_{50} \mathrm{Mg}_{48} \mathrm{Ni}_{7}, \mathrm{Mg}_{2} \mathrm{Zn}$, $\mathrm{Al}_{4} \mathrm{Ni}_{3}, \mathrm{Al}_{75} \mathrm{Ni}_{10} \mathrm{Fe}_{15}$, and $\mathrm{Al}_{3} \mathrm{Ni}_{2}$ ). The outcomes of the XRD analysis indicated coexistence of nickel-rich intermetallic compounds within the matrix of the alloy A. According to the phase diagrams for an $\mathrm{Al}-\mathrm{Ni}, \mathrm{Al}-\mathrm{Cu}-\mathrm{Ni}$ and $\mathrm{Al}-\mathrm{Fe}-\mathrm{Ni}$ phases by [18] showed that Nickel could combine with $\mathrm{Al}, \mathrm{Cu}$, and Fe to form the intermetallics.

The generally accepted precipitation sequences for a 7000 series aluminum alloys are as follows: supersaturated solid solution $\rightarrow$ coherent stable Guinier-Preston (GP) zones $\rightarrow$ semicoherent intermediate $\eta^{\prime}\left(\mathrm{Mg}_{2} \mathrm{Zn}_{11}\right)$ phase (metastable $\eta\left(\mathrm{MgZn}_{2}\right)$ or $\mathrm{T}\left(\mathrm{AlMg}_{4} \mathrm{Zn}_{11}\right)$ phase $)[19,20]$. The primary precipitations in the matrix are the GP zones and the $\eta^{\prime}$ phase after aging at $120^{\circ} \mathrm{C}$ for $24 \mathrm{~h}$.

The XRD plots in Figure 7(b) show that the alloy "A" sample after $\mathrm{T} 6$ temper exhibits dispersoid compound phases $\left(\mathrm{Mg}_{2} \mathrm{Zn}_{11}, \mathrm{MgZn}_{2}, \mathrm{Al}_{75} \mathrm{Ni}_{10} \mathrm{Fe}_{15}\right.$, and $\left.\mathrm{Al}_{4} \mathrm{Ni}_{3}\right)$ in addition to 


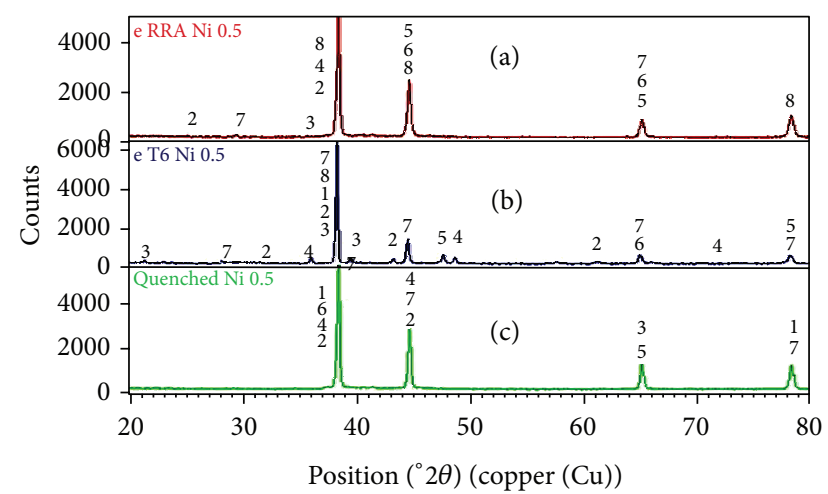
(1) $\mathrm{Al}_{5} \mathrm{Mg}_{11} \mathrm{Zn}_{4}, \mathrm{AlCuMg}$
(2) $\mathrm{Al}_{7} \mathrm{Cu}_{4} \mathrm{Ni}$
(3) $\mathrm{Al}_{50} \mathrm{Mg}_{48} \mathrm{Ni}_{7}$
(4) $\mathrm{Al}_{4} \mathrm{Ni}_{3}$
(5) $\mathrm{Al}_{3} \mathrm{Ni}_{2}$
(6) $\mathrm{Al}_{75} \mathrm{Ni}_{10} \mathrm{Fe}_{15}$
(7) $\mathrm{MgZn}_{2}$
(8) $\mathrm{Mg}_{2} \mathrm{Zn}_{11}$

FIgURE 7: The XRD plots for alloy A: after quenching, T6 heat treatment, and RRA process.

the compounds already existing in the as quenched sample of alloy A. These dispersive phases have high peaks as a result of intensive dissolution of the alloying elements and the nickel additives in the matrix which are brought by homogenization, extrusion, and subsequent heat treatments. On the other hand, $\mathrm{Li}$ et al. [21] found that adding nickel to an Al-Zn$\mathrm{Mg}-\mathrm{Cu}$ alloy suppresses the formation in the $\mathrm{MgZn}_{2}$ phase in the matrix. Findings of $\mathrm{Li}$ et al. came in contradiction to the outcomes of EDS and XRD analysis through this study which revealed plentiful of $\mathrm{MgZn}_{2}$ phases.

The XRD analysis in Figure 7(a) for the alloy "A" sample after the RRA process indicates high-intensity diffraction peaks of the $\mathrm{Al}_{4} \mathrm{Ni}_{3}, \mathrm{Al}_{3} \mathrm{Ni}_{2}, \mathrm{Al}_{75} \mathrm{Ni}_{10} \mathrm{Fe}_{15}$, and $\eta\left(\mathrm{MgZn}_{2}\right)$ with $\eta^{\prime}\left(\mathrm{Mg}_{2} \mathrm{Zn}_{11}\right)$ phases. Generally it had been suggested by $\mathrm{Li}$ et al. [22] that during the high temperature of the retrogression process $\left(180^{\circ} \mathrm{C}\right.$ for 30 minutes as in this study) undissolved GP zones transformed into $\eta^{\prime}$ phase and thus formed numerous GP zones and $\eta^{\prime}$ phases. The results were consistent with $\mathrm{XRD}$ results through this study. Finally, plenty of the GP zones and $\eta^{\prime}$-phase $\left(\mathrm{Mg}_{2} \mathrm{Zn}_{11}\right)$ re-precipitation during the reaging step.

The SEM micrograph in Figure 8(a) shows the microstructure of the as-quenched alloy "B" sample. The dark areas denote the primary solid solution. Gray particles are observed in the encircled region (X). The EDS microanalysis detects the reduced concentrations of magnesium and zinc noticing that the stoichiometry of tin (Sn) has the high concentration (Figure 8(b)). The bright areas denote the nonequilibrium solidification eutectic system between grains as indicated in the enlarged labeled region (Figure 8(c)).

The SEM micrograph in Figure 9(a) of the alloy B sample after T6 temper indicates the prevalence of the Ni-affluent dispersoids particles. The encircled region $(\mathrm{Y})$ shows a rod shape as in Figure 9(c). The EDS microanalysis results of this region in Figure 9(b) reveal the chemical composition close to the $\mathrm{T}-(\mathrm{Al} \mathrm{Mg} \mathrm{Zn})$ and the $\mathrm{S}-(\mathrm{Al} \mathrm{Cu} \mathrm{Mg})$ phase with $\gamma$-(Al$\mathrm{Cu}-\mathrm{Ni}-\mathrm{Fe}$ ) phases and $\mathrm{Al} \mathrm{Cu} \mathrm{Sn}$ phase.
Figure 10 shows the microstructure of the alloy A sample after the RRA process. Figure 10(a) shows the numerous dispersion particle phases as bright areas and the region (Z) indicates Chinese script morphology (see Figure 10(c) for highly magnified SEM). Figure 10(b) reveals similar stoichiometry to $\mathrm{T}-(\mathrm{Al} \mathrm{Mg} \mathrm{Zn})$ phase and $\mathrm{S}-(\mathrm{Al} \mathrm{Cu} \mathrm{Mg})$ phase with $\gamma-(\mathrm{Al}-\mathrm{Cu}-\mathrm{Ni}-\mathrm{Fe})$ phases, (Al-Cu-Sn) and (Al-Ni-Sn) phases. Sn element is peaked highly in the EDS analysis.

The XRD analysis results of the alloy $B$ samples are shown in Figures 11(a)-11(c) (RRA, T6, and as-quenched, resp.). The patterns of the as-quenched alloy B sample confirm that the principle eutectic mainly consisted of $\alpha(\mathrm{Al})$, solid solution, and intermetallic compounds.

Figure 11(b) shows the XRD plots of the alloy B sample undergoing $\mathrm{T} 6$ temper which indicates coexistence of the dispersoids particles of the $\mathrm{Al}_{7} \mathrm{Cu}_{4} \mathrm{Ni}$ and $\mathrm{Al}_{4} \mathrm{Ni}_{15} \mathrm{Sn}$ in addition to the compounds which were peaked highly such as $\mathrm{Al}_{4} \mathrm{Ni}_{3}, \mathrm{Al}_{75} \mathrm{Ni}_{10} \mathrm{Fe}_{15}$, and $\mathrm{Al}_{3} \mathrm{Cu}_{12} \mathrm{Sn}$. Dispersed phases possessed high peaks because of the intensive dissolution of the alloying elements and the nickel combined with $S n$ element produced by a series of the homogenization and subsequent heat treatments.

Figure 11(a) shows the XRD plots for the alloy B sample after the RRA process. The intensity of the diffraction peaks $\mathrm{Al}_{4} \mathrm{Ni}_{15} \mathrm{Sn}$ and other peaked high such as $\mathrm{Al}_{7} \mathrm{Cu}_{4} \mathrm{Ni}, \mathrm{Al}_{4} \mathrm{Ni}_{3}$, $\mathrm{Al}_{75} \mathrm{Ni}_{10} \mathrm{Fe}_{15}$ and $\mathrm{Al}_{3} \mathrm{Cu}_{12} \mathrm{Sn}$ phases with a little coexistence of the $\mathrm{Mg}_{2} \mathrm{Zn}_{11}$ phase. The reason standing behind disappearance of some of the compounds in the MgZn phase through adding $0.5 \mathrm{wt} . \% \mathrm{Sn}$ into the alloy $\mathrm{A}$ is attributed to the impacts of tin (Sn) in the nucleation within the vicinity of the grain boundaries which is resulting in the suppression of some of the sites, the creation for the MgZn phases within the matrix alloy B in this study present. This justification conforms with prior researchers: Ogura et al. [23] observed that adding tin element into $\mathrm{Al}-\mathrm{Zn}-\mathrm{Mg}$ alloy led to precipitates suppression of the MgZn phases which are sparsely formed within the microstructure. The outcomes of XRD analysis of alloy B conform to the EDS scan results as noticed in Figure 10(b).

After applying the aging at $\mathrm{T} 6$ temper and RRA process for the alloy $\mathrm{A}$ and alloy $\mathrm{B}$, the yield maximum gains of about 385 and $415 \mathrm{MPa}$ and 370 and $385 \mathrm{MPa}$ were attained in the ultimate tensile strength (UTS), respectively. Figure 12 shows the variation in the UTS value among samples of the as-quenched alloys and same the samples which underwent T6 temper and the RRA process. This is due to the grain refinement and the evolution of the new interdendritic networks brought about by the intensive extrusion process and the heat treatment processes as shown earlier in Figures 1 and 2.

Figure 13 shows the variations in the Vickers hardness of the alloy specimens under different heat treatments. Generally, alloys A and B are gaining about 110 and $120 \mathrm{HV}$, respectively, after undergoing the T6 and RRA process. Principally the hardness scale depends on the extrusion process which led to reducing the grain size as well as the influence of the ageing treatment which was included on the distribution of precipitates and dispersion phases of the additives in the matrix during these processes. 


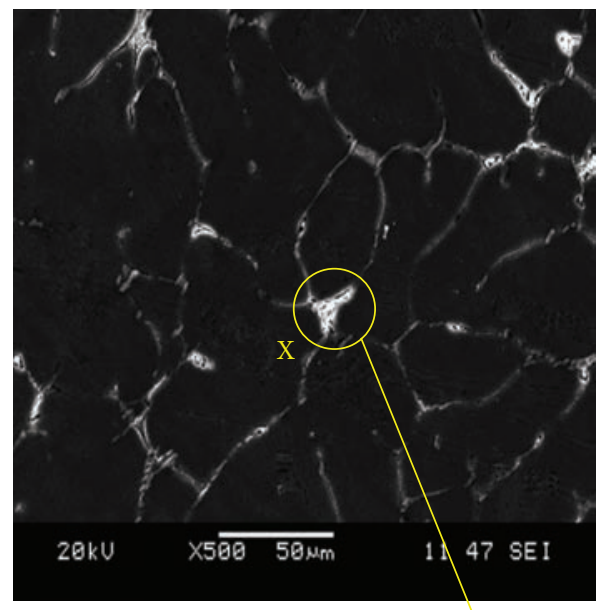

(a)

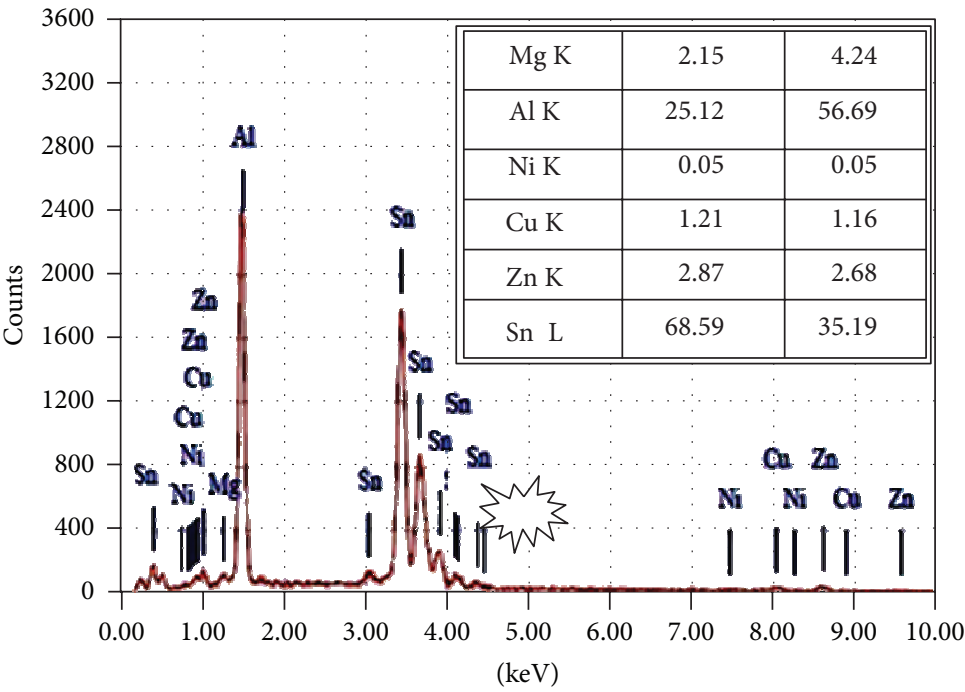

(b)

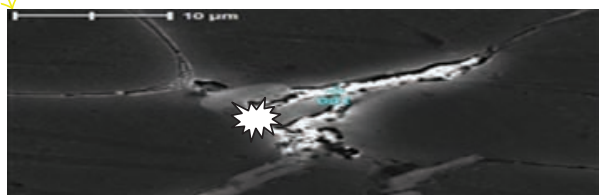

(c)

FIGURE 8: The (a) SEM micrograph and (b) EDS microanalysis for the as-quenched alloy B sample.

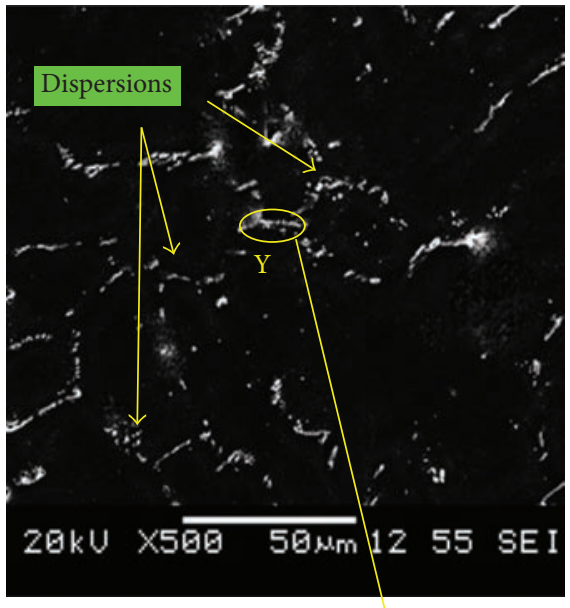

(a)

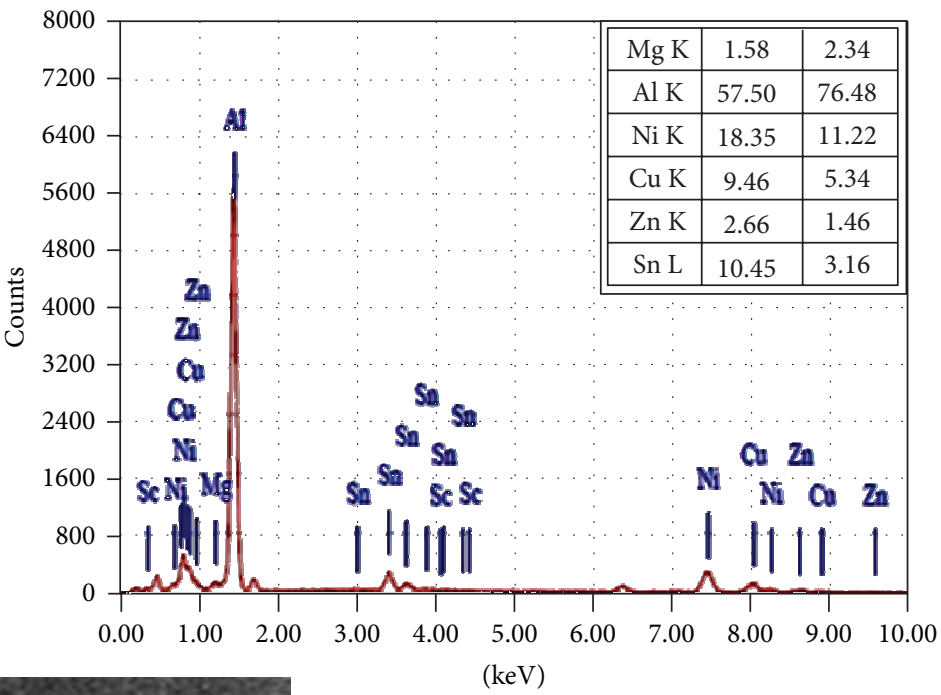

(b)

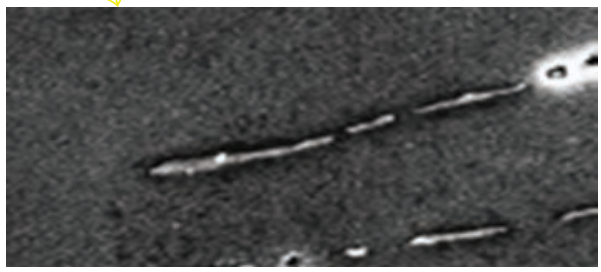

(c)

FIgURE 9: The (a) SEM micrograph and (b) EDS microanalysis of alloy B sample after having undergone T6 heat treatment. 


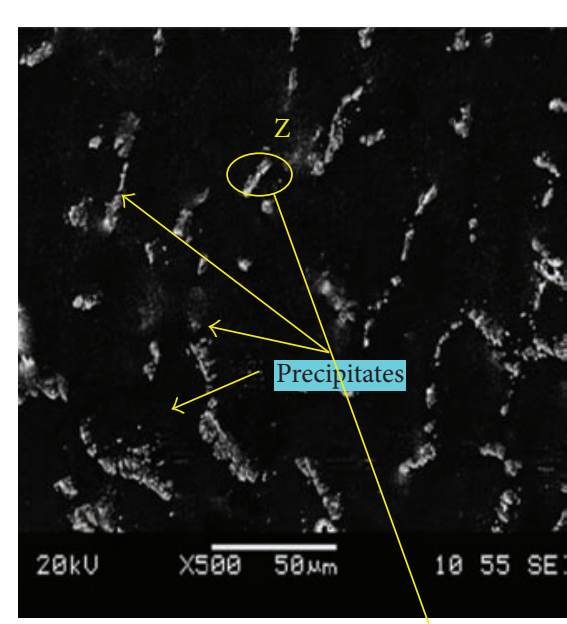

(a)

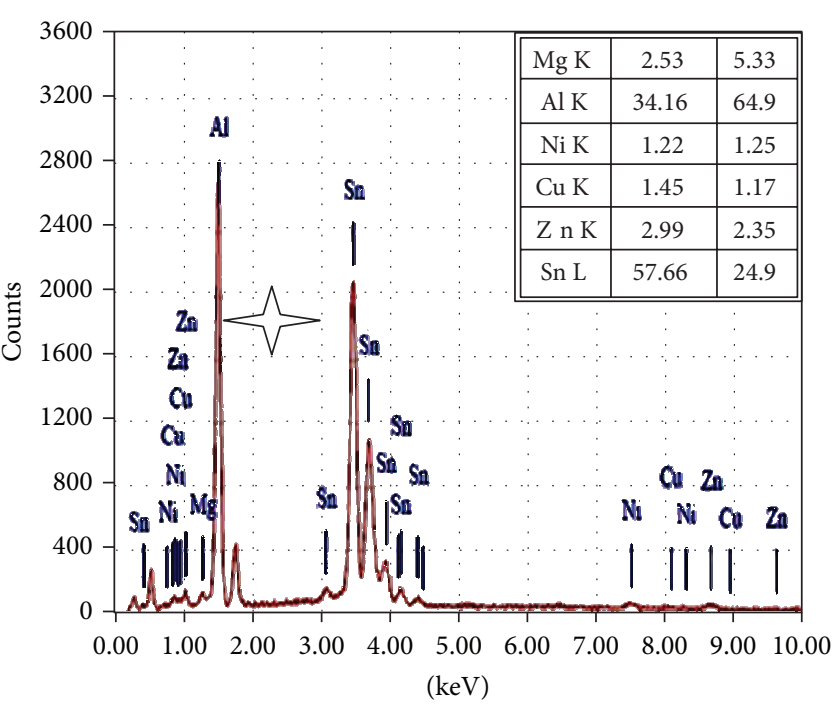

(b)

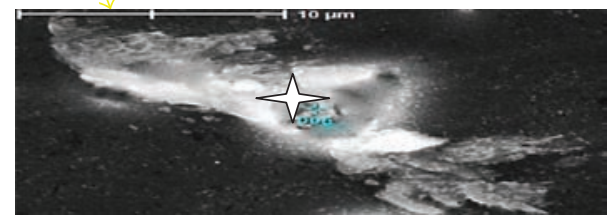

(c)

FIGURE 10: The (a) SEM micrograph and (b) EDS microanalysis of alloy B sample after having undergone RRA process.

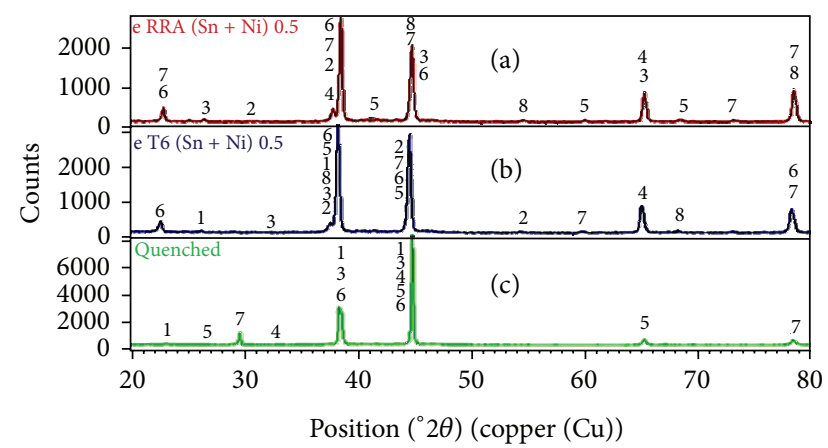
(1) $\mathrm{Al}, \mathrm{Al}_{5} \mathrm{Mg}_{11} \mathrm{Zn}_{4}, \mathrm{AlCuMg}$
(2) $\mathrm{Al}_{7} \mathrm{Cu}_{4} \mathrm{Ni}$
(3) $\mathrm{Al}_{50} \mathrm{Mg}_{48} \mathrm{Ni}_{7}$
(5) $\mathrm{AL}_{75} \mathrm{Ni}_{10} \mathrm{Fe}_{15}$
(6) $\mathrm{Mg}_{2} \mathrm{Zn}_{11}$
(7) $\mathrm{Al}_{3} \mathrm{Cu}_{12} \mathrm{Sn}$
(4) $\mathrm{Al}_{4} \mathrm{Ni}_{3}$
(8) $\mathrm{Al}_{4} \mathrm{Ni}_{15} \mathrm{Sn}$

FIGURE 11: The XRD plots for alloy B (a) after the RRA process (b) after the T6 heat treatment and (c) the as-quenched.

\section{Discussion}

The results indicated that the yield strength (YS), ultimate tensile strength (UTS), and Vickers hardness of both alloys A and B substantially improved after the T6 temper and RRA treatment.

The strengthening mechanisms alloys (A and $\mathrm{B})$ divided into the precipitation hardening in addition to dispersion strengthening. The precipitation hardening was detailed by [20-22]. The dispersion strengthening can be described as dislocations inhibited by $\mathrm{Ni}$ or/and $\mathrm{Sn}$ dispersoid in the slipping planes. Assumption of dispersoids, that the dispersed phase particles were looped, bypassed, and/or sheared by dislocation through the Orowan mechanism. The stress required to move a dislocation around a particle is YS, which is increased by dispersion strengthening. So the increase in the yield strength (YS) due to the Orowan strengthening, $\Delta \sigma y$, Or was given by $[24,25]$

$$
\Delta \sigma y, O r=\frac{2 G b}{L d}
$$

where $G$ is the shear modulus of the matrix, $b$ is Burger's vector of the dislocation, and $L d$ is the interparticle spacing of the dispersoids. The XRD analysis indicated that the extrusion and the heat treatments (T6 temper and the RRA process) on alloys A and B have resulted in lower $L d$ spacing as compared to the $L d$ values of the parent alloy phases as shown in Table 3. Thus according to (1) the yield strength is high for the alloys A and B.

\section{Conclusions}

(1) Microstructures observations for alloys revealed the presence of phases such as $\mathrm{Al}_{7} \mathrm{Cu}_{4} \mathrm{Ni}, \mathrm{Al}_{4} \mathrm{Ni}_{3}$, $\mathrm{Al}_{50} \mathrm{Mg}_{48} \mathrm{Ni}_{7}, \mathrm{Al}_{75} \mathrm{Ni}_{10} \mathrm{Fe}_{15}, \mathrm{Al}_{3} \mathrm{Ni}_{2}, \mathrm{Al}_{4} \mathrm{Ni}_{15} \mathrm{Sn}$, and $\mathrm{Al}_{3} \mathrm{Cu}_{12} \mathrm{Sn}$ which are standing behind the dispersoids particles through heat combined with mechanical treatments. 


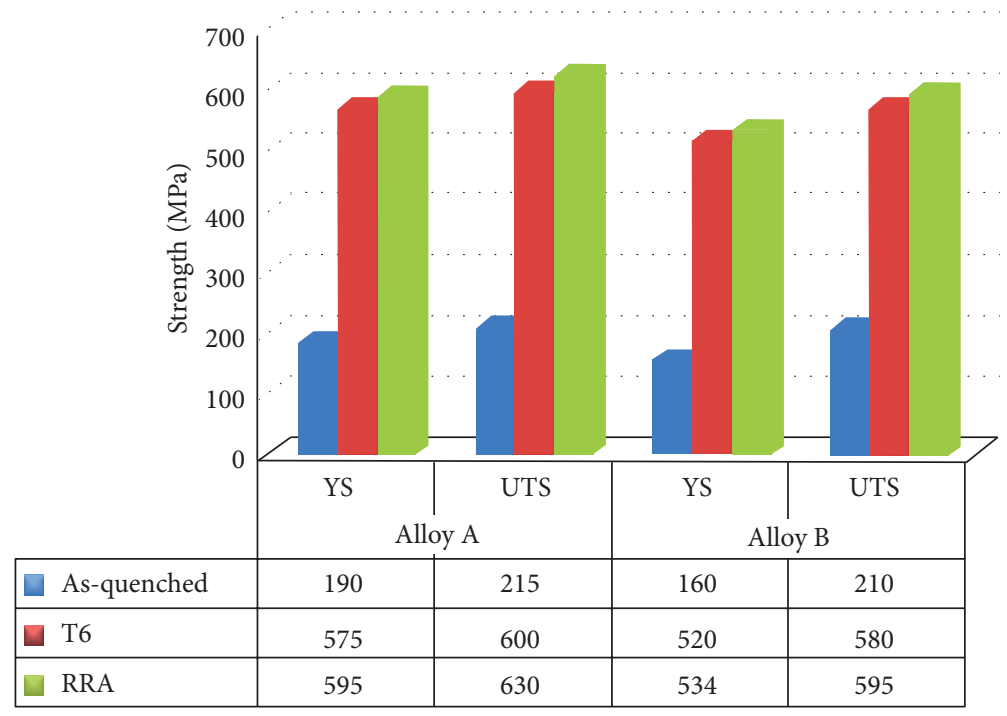

FIGURE 12: Variations of the tensile strength for alloys samples after different heat treatments.

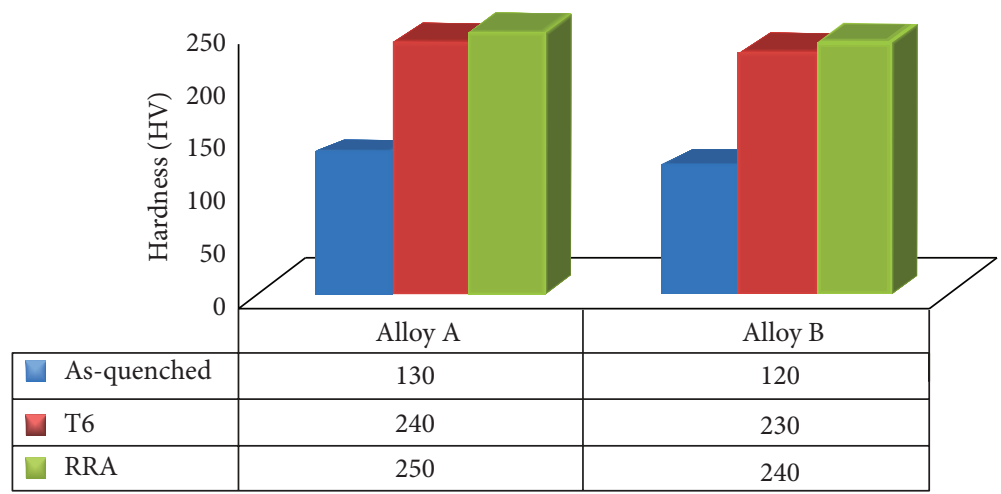

FIGURE 13: Indicating the variations in the Vickers hardness of the alloy specimens under different conditions.

TABLE 3: The XRD results of the compounds phase which appeared in the two tested alloys.

\begin{tabular}{lcc}
\hline Alloys & Intermetallics compounds & $d$-spacing $(\AA)$ \\
\hline \multirow{2}{*}{ Base alloy } & $\mathrm{Al}_{5} \mathrm{Mg}_{11} \mathrm{Zn}_{4}$ & 2.35605 \\
& $\mathrm{Al}_{2} \mathrm{CuMg}$ & 2.31249 \\
& $\mathrm{Mg}_{2} \mathrm{Zn}_{11}$ & 2.07419 \\
& $\mathrm{MgZn}_{2}$ & 2.16920 \\
\hline \multirow{3}{*}{ Alloy A } & $\mathrm{Al}_{7} \mathrm{Cu}_{4} \mathrm{Ni}$ & 2.04391 \\
& $\mathrm{Al}_{4} \mathrm{Ni}_{3}$ & 2.01674 \\
& $\mathrm{Al}_{75} \mathrm{Ni}_{10} \mathrm{Fe}_{15}$ & 2.05108 \\
& $\mathrm{Al}_{3} \mathrm{Ni}_{2}$ & 2.00637 \\
\hline \multirow{2}{*}{ Alloy B } & $\mathrm{Al}_{3} \mathrm{Cu}_{12} \mathrm{Sn}$ & 2.1010 \\
& $\mathrm{Al}_{4} \mathrm{Ni}_{15} \mathrm{Sn}$ & 2.0789 \\
\hline
\end{tabular}

(2) The mechanical properties of (Al-Zn-Mg-Cu-Ni) alloy $\mathrm{A}$ after the retrogression and reaging processes led to raising the ultimate tensile strength to high level to be about $630 \mathrm{MPa}$ and Vickers hardness being about $250 \mathrm{HV}$.
(3) With adequate additions of tin into (Al- $\mathrm{Zn}-\mathrm{Mg}-\mathrm{Cu}-$ $\mathrm{Ni}$ ) alloy $\mathrm{B}$, the alloy exhibited the strength and hardness values: yield strength $534 \mathrm{MPa}$, ultimate tensile strength about $595 \mathrm{MPa}$, and Vickers hardness $240 \mathrm{MPa}$ were which attained after the RRA treatment. The strength of alloy B was lower than alloy A because of adding tin element which suppresses some of the $\mathrm{MgZn}$ compounds phases.

(4) Generally, the incremental increase in the strength of alloys $\mathrm{A}$ and $\mathrm{B}$ through the present study was due to the precipitation hardening and Orowan strengthening which are working together.

\section{Conflict of Interests}

The authors declare that there is no conflict of interests regarding the publication of this paper.

\section{Acknowledgments}

This work is supported under Grant no. 9001-00338 of the University Malaysia Perlis (UniMAP). The authors gratefully 
acknowledge the outstanding support provided by the technicians of the workshop in the Materials Engineering School, UniMAP.

\section{References}

[1] L. Huang, K. Chen, and S. Li, "Influence of grain-boundary pre-precipitation and corrosion characteristics of inter-granular phases on corrosion behaviors of an Al-Zn-Mg-Cu alloy," Materials Science and Engineering B, vol. 177, no. 11, pp. 862-868, 2012.

[2] C. Feng, Z. Liu, A. Ning, and S. Zeng, "Effect of low temperature aging on microstructure and mechanical properties of superhigh strength aluminum alloy," Journal of Central South University of Technology, vol. 13, no. 5, pp. 461-467, 2006.

[3] P. Z. Zhao and T. Tsuchida, "Effect of fabrication conditions and $\mathrm{Cr}, \mathrm{Zr}$ contents on the grain structure of 7075 and 6061 aluminum alloys," Materials Science and Engineering A, vol. 499, no. 1-2, pp. 78-82, 2009.

[4] A. K. Chaubey, S. Mohapatra, K. Jayasankar et al., "Effect of cerium addition on microstructure and mechanical properties of Al-Zn-Mg-Cu alloy," Transactions of the Indian Institute of Metals, vol. 62, no. 6, pp. 539-543, 2009.

[5] X.-G. Dong, J. Zhou, Y.-J. Jia, and B. Liu, "Effect of alloying on high temperature fatigue performance of ZL114A (Al-7Si) alloy ," Transactions of Nonferrous Metals Society of China, vol. 22, supplement 3, pp. s661-s667, 2012.

[6] A. R. Farkoosh, M. Javidani, M. Hoseini, D. Larouche, and M. Pekguleryuz, "Phase formation in as-solidified and heattreated $\mathrm{Al}-\mathrm{Si}-\mathrm{Cu}-\mathrm{Mg}-\mathrm{Ni}$ alloys: thermodynamic assessment and experimental investigation for alloy design," Journal of Alloys and Compounds, vol. 551, pp. 596-606, 2013.

[7] J. Shen, R. Liu, Y. Liu, Z. Jiang, and Q. Li, "Microstructures and tensile properties of spray-deposited high-strength aluminium alloys," Journal of Materials Science, vol. 32, no. 3, pp. 829-832, 1997.

[8] Y. Wu, F. H. Froes, C. Li, and A. Alvarez, "Microalloying of Sc, $\mathrm{Ni}$, and $\mathrm{Ce}$ in an advanced $\mathrm{Al}-\mathrm{Zn}-\mathrm{Mg}-\mathrm{Cu}$ alloy," Metallurgical and Materials Transactions A, vol. 30, no. 4, pp. 1017-1024, 1999.

[9] W.-B. Li, Q.-L. Pan, Y.-P. Xiao, Y.-B. He, and X.-Y. Liu, "Microstructural evolution of ultra-high strength Al-Zn-Cu$\mathrm{Mg}-\mathrm{Zr}$ alloy containing Sc during homogenization," Transactions of Nonferrous Metals Society of China, vol. 21, no. 10, pp. 2127-2133, 2011.

[10] G.-S. Peng, K.-H. Chen, S.-Y. Chen, and H.-C. Fang, "Influence of dual retrogression and re-aging temper on microstructure, strength and exfoliation corrosion behavior of $\mathrm{Al}-\mathrm{Zn}-\mathrm{Mg}-\mathrm{Cu}$ alloy," Transactions of Nonferrous Metals Society of China, vol. 22, no. 4, pp. 803-809, 2012.

[11] M. Lalpoor, D. G. Eskin, and L. Katgerman, "Cold cracking development in AA7050 direct chill-cast billets under various casting conditions," Metallurgical and Materials Transactions A, vol. 41, no. 9, pp. 2425-2434, 2010.

[12] D. G. Eskin, Physical Metallurgy of Direct Chill Casting of Aluminum Alloys, CRC Press, New York, NY, USA, 2008.

[13] O. P. Gbenebor, M. Abdulwahab, and O. S. I. Fayomi, "Influence of inoculant addition and cooling medium on the mechanical properties of aa 6063-type Al-Mg-Si alloy," Chalcogenide Letters, vol. 9, no. 5, pp. 201-211, 2012.

[14] R. Nadella, D. G. Eskin, Q. Du, and L. Katgerman, "Macrosegregation in direct-chill casting of aluminium alloys," Progress in Materials Science, vol. 53, no. 3, pp. 421-480, 2008.
[15] H. T. Naeem, K. S. Mohammad, K. R. Ahmad, and A. Rahmat, "The role of direct chilling, retrogression and reaging treatment on mechanical properties of high strength aluminum alloy," Advance Materials Research, vol. 795, pp. 211-218, 2013.

[16] Y. Deng, Z. Yin, and F. Cong, "Intermetallic phase evolution of 7050 aluminum alloy during homogenization," Intermetallics, vol. 26, pp. 114-121, 2012.

[17] Y. He, X. Zhang, and Z. Cao, "Effect of minor Cr, Mn, Zr, Ti and $\mathrm{B}$ on grain refinement of as-cast $\mathrm{Al}-\mathrm{Zn}-\mathrm{Mg}$-Cu alloys," Rare Metal Materials and Engineering, vol. 39, no. 7, pp. 1135-1140, 2010.

[18] V. S. Zolotorevsky and N. A. Belov, Casting Aluminum Alloys, Alcoa Technical Center, Alcoa Center, New Kensington, Pa, USA, 2007.

[19] G.-S. Peng, K.-H. Chen, S.-Y. Chen, and H.-C. Fang, "Influence of dual retrogression and re-aging temper on microstructure, strength and exfoliation corrosion behavior of $\mathrm{Al}-\mathrm{Zn}-\mathrm{Mg}-\mathrm{Cu}$ alloy," Transactions of Nonferrous Metals Society of China, vol. 22, no. 4, pp. 803-809, 2012.

[20] X. W. Li, B. Q. Xiong, Y. A. Zhang et al., "Retrogression and re-aging treatment of $\mathrm{Al}-9.99 \% \mathrm{Zn}-1.72 \% \mathrm{Cu}-2.5 \% \mathrm{Mg}-0.13 \% \mathrm{Zr}$ aluminum alloy," Transactions of Nonferrous Metals Society of China, vol. 16, no. 5, pp. 1163-1170, 2006.

[21] L. Li, T. Zhou, H. Li, C. Chen, B. Xiong, and L. Shi, "Effect of additional elements on aging behavior of $\mathrm{Al}-\mathrm{Zn}-\mathrm{Mg}-\mathrm{Cu}$ alloys by spray forming," Transactions of Nonferrous Metals Society of China, vol. 16, no. 3, pp. 532-538, 2006.

[22] G. Li, X. Zhang, P. Li, and J. You, "Effects of retrogression heating rate on microstructures and mechanical properties of aluminum alloy 7050," Transactions of Nonferrous Metals Society of China, vol. 20, no. 6, pp. 935-941, 2010.

[23] T. Ogura, S. Hirosawa, A. Hirose, and T. Sato, "Effects of microalloying tin and combined addition of silver and tin on the formation of precipitate free zones and mechanical properties in Al-Zn-Mg alloys," Materials Transactions, vol. 52, no. 5, pp. 900-905, 2011.

[24] J. Wang, D. Yi, X. Su, and F. Yin, "Influence of deformation ageing treatment on microstructure and properties of aluminum alloy 2618," Materials Characterization, vol. 59, no. 7, pp. 965968, 2008.

[25] Z. Zhang, K. Chen, H. Fang, X. Qi, and G. Liu, "Effect of Yb addition on strength and fracture toughness of Al-Zn-Mg-CuZr aluminum alloy," Transactions of Nonferrous Metals Society of China, vol. 18, no. 5, pp. 1037-1042, 2008. 

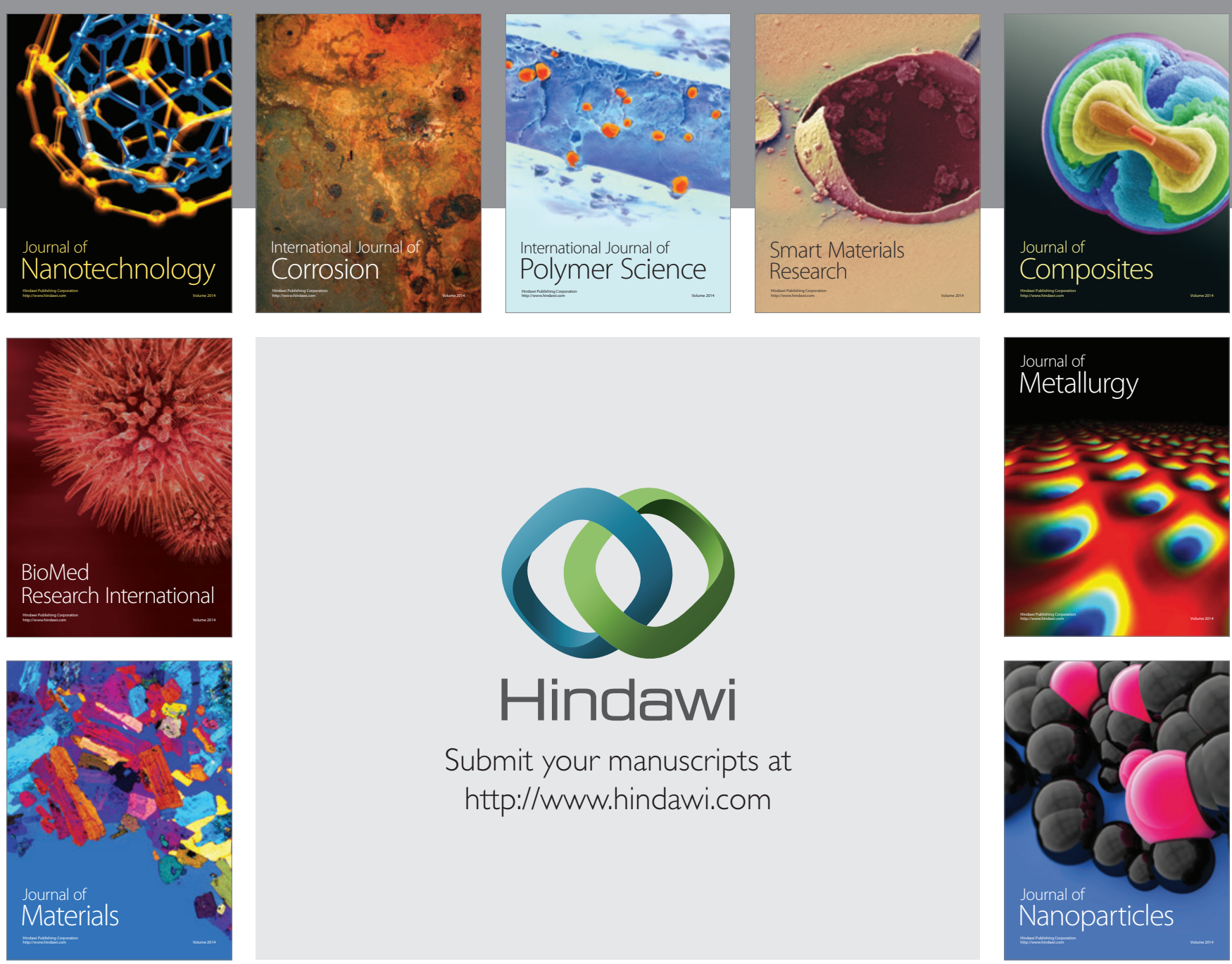

Submit your manuscripts at http://www.hindawi.com


\section{The Scientific World Journal}
